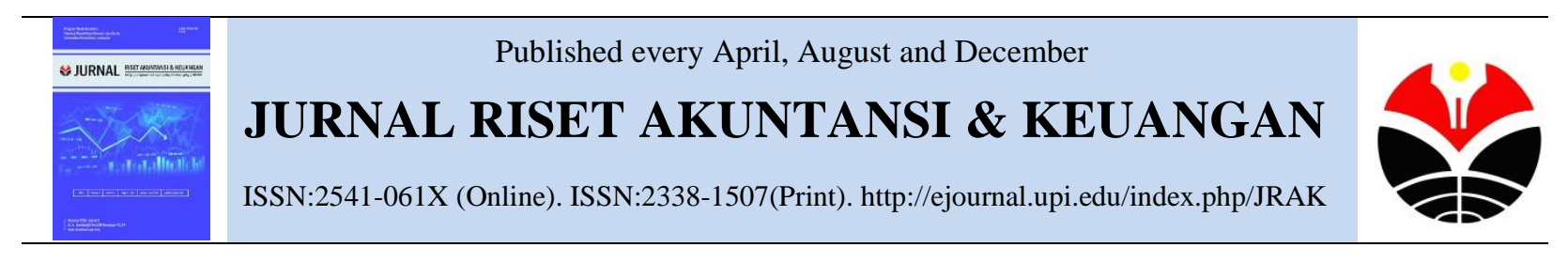

\title{
Penerapan Pengukuran Nilai Wajar PSAK-Konvergensi IFRS dan Dampaknya pada Pilihan Kebijakan Akuntansi di Indonesia
}

\author{
Siti Khomsatun \\ Program Studi Akuntansi Islam, Sekolah Tinggi Ekonomi Islam (STEI) Tazkia, Bogor, Indonesia
}

\begin{abstract}
This study aims to investigate the impact of the compulsory measurement of fair value and choice on the comparability of financial statements. This study uses data of non-financial public companies listed on the BEI. The method of determining the appeal level using the Taplin index and the increase or decrease of the appeal rate using the different test of Mc Nemar and Wilcoxon. The results show that there is no increase in the comparability of financial statements for accounting policies required to use value measurement. The accounting policy allowed to choose the method of measurement is also not proven there is a decrease in the comparability of financial statements. Differences in appeals occur only in the accounting policies of fixed assets that have increased appeal. This study shows that before and after the adoption of new standards related to fair value measurement, the financial reporting appeal level is still high. This study also indicates that the fair value measurement for the accounting policy allowed to select the measurement method is still low.
\end{abstract}

Keyword: Measurement of Fair Value; Power of Appeals; Choice of Accounting, Index-Taplin

Abstrak. Penelitian ini bertujuan untuk menginvestigasi dampak pengukuran nilai wajar yang diwajibkan dan pilihan terhadap daya banding laporan keuangan.Penelitian ini menggunakan data perusahaan publik non keuangan yang tercatat di BEI. Metode penentuan tingkat daya banding dengan menggunakan indeks Taplin dan peningkatan atau penurunan tingkat daya banding menggunakan uji beda Mc Nemar dan Wilcoxon. Hasil penelitian menunjukkan bahwa tidak ada peningkatan daya banding laporan keuangan untuk kebijakan akuntansi yang diwajibkan menggunakan pengukuran nilai.Kebijakan akuntansi yang diperbolehkan memilih metode pengukuran juga tidak terbukti terdapat penurunan daya banding laporan keuangan.Perbedaan daya banding terjadi hanya pada kebijakan akuntansi Aset Tetap yang mengalami kenaikan daya banding.Penelitian ini menunjukkan bahwa sebelum dan setelah penerapan standar baru terkait pengukuran nilai wajar, tingkat daya banding laporan keuangan masih tinggi.Penelitian ini juga mengindikasikan bahwa tingkat pengukuran nilai wajar untuk kebijakan akuntansi yang diperbolehkan memilih metode pengukuran masih rendah.

Kata Kunci: Pengukuran Nilai Wajar; Daya Banding; Pilihan Akuntansi, Indeks-Taplin

Corresponding author. Email. khomsahtazkia@yahoo.com. J1. Ir H. Juanda No. 78, Sentul City, Bogor, 16810

How to cite this article. Khomsatun, S. (2016). Penerapan Pengukuran Nilai Wajar PSAK-Konvergensi IFRS dan Dampaknya pada Pilihan Kebijakan Akuntansi di Indonesia. Jurnal Riset Akuntansi Dan Keuangan Program Studi Akuntansi Fakultas Pendidikan Ekonomi Dan Bisnis Universitas Pendidikan Indonesia, 4(2), 967-984. Retrieved from http://ejournal.upi.edu/index.php/JRAK/article/view/4031

History of article. Received: Mei 2016, Revision: Juli 2016, Published: Agustus 2016

Online ISSN: 2541-061X.Print ISSN: 2338-1507. DOI: 10.17509/jrak.v4i2.4031

Copyright@2016. Jurnal Riset Akuntansi dan Keuangan Program Studi Akuntansi FPEB UPI 


\section{PENDAHULUAN}

Kebijakan teknik pengukuran akuntansi masih menjadi isu yang sangat menarik untuk dikaji. Pengukuran nilai historis merupakan pengukuran masa lalu dan banyak kalangan menilai tingkat relevansi nilai historis tidak bisa terpenuhi. Sedangkan pengukuran nilai wajar dianggap memenuhi relevansi tetapi tidak memenuhi keandalan (realible) karena permasalahan di teknik pengukuran.Kondisi keduanya menyebabkantrade-off relevansi dan keandalan(KDDPLK, Paragraf 45).

Pengguna informasi akuntansi mengharapkan laporan yang diterima bisa merefleksikan keadaan masa kini dan dapat dijadikan alat untuk prediksi. Kang (2007) menyebutkan dengan menggunakan akuntansi nilai wajar dapat meningkatkan prediksi nilai ekonomis masa depan. Dixon \&Frolova (2013) menyatakan bahwa implementasi nilai wajarakan meningkatkan relevansi laporan keuangan. Sedangkan Taylor (2009) menjelaskan bahwa penyajian laporan keuangan menggunakan nilai wajar menyebabkan kinerja keuangan lebih fluktuatif. Adapun Allen dan Carletti (2008) menyebutkan bahwa nilai historis masih lebih berguna dibanding nilai wajar.

Pengukuran nilai wajar memang merupakan isu yang mengalami perdebatan sangat panjang dan kontroversial (Christensen dan Nikolaev, 2009). Ketika terjadi krisis global di Amerika tahun 2008 yang disebabkan oleh skandal subprime mortgage, pengukuran nilai wajar sempat dijadikan penyebab. Laux dan Leuz (2010) menyebut bahwa nilai wajar berkontribusi dalam krisis keuangan perbankan United States. Kritik tersebut dibantah oleh hasil penelitian Gladney (2011) yang menyebutkan bahwa nilai wajar tidak kuat untuk menimbulkan dan menjadi sumber terjadinya krisis keuangan.

Salah satu isu dalam adopsi International Financial Reporting Standard (IFRS) adalah tentang aturan pengukuran nilai wajar. IFRS masih mengatur metode pengukuran dengan mixed method, yaitu adanya opsi/memilih penggunaan metode biaya atau nilai wajar, walaupun ada beberapa kebijakan akuntansi tertentu yang diharuskan melakukan pengukuran dengan nilai wajar.

Dewan Standar Akuntansi di Indonesiamenyatakan diri untuk melakukan konvergensi IFRS secara penuh per 1 Januari 2012.Sejalan dengan IFRS, beberapa standar akuntansi di Indonesia juga mengatur tentang pengukuran nilai wajar, baik yang bersifat wajib (mandatory) maupun sukarela (opsi). Hal ini ditandai dengan diterbitkan beberapa Pernyataan Standar Akuntansi Keuangan (PSAK) yang mengatur pengukuran nilai wajar yang dimulai dengan diterbitkannya PSAK 50 dan 55 (revisi 2006) tentang instrumen keuangan. Setahun setelahnya, disahkan PSAK 13 tentang Properti Investasi dan PSAK 16 tentang Aset Tetap yang disahkan pada tanggal 29 Mei 2007 dan berlaku efektif per 1 Januari 2008 (PSAK Per 1 September 2007).

Pilihan pengukuran nilai wajar tersebut menurut Cairns et al. (2011) dapat berdampak pada daya banding.Hasil penelitian Cairns et al. menyebutkan bahwa jika pengukuran nilai wajar disyaratkan (mandatory) oleh standar maka dapat meningkatkan daya banding. Sebaliknya, jika pengukuran nilai wajar diizinkan (opsi) oleh standar, maka menurunkan daya banding.

Tujuan dari adopsi/konvergensi IFRS adalah untuk meningkatkan kualitas laporan keuangan.Salah satu yang menjadi parameter kualitas laporan keuangan adalah dengan meningkatnya daya banding laporan keuangan (KDDPLK).Ketika perusahaan lintas negara mengacu pada satu standar internasional maka daya banding laporan keuangan secara internasional juga meningkat.Dengan demikian tujuan one-single international accounting standard dapat tercapai.

Terkait dengan pengukuran nilai wajar, baik yang bersifat wajib maupun pilihan, beberapa penelitian telah dilakukan.Watt \& Zimmerman (1986) mengatakan bahwa jika ada suatu standar baru dikeluarkan, maka ada konsekuensi ekonomi dalam pemilihan metode akuntansi.Penelitian terdahulu sudah banyak yang melakukan investigasi harmonisasi dengan melakukan kajian pada daya banding standar akuntansi dan 
praktiknya. Diantaranya yaitu Archer, Delvaille, \& McLeay, 1995; Emenyonu \& Gray, 1992; Herrman \& Thomas, 1995; Parker \& Morris, 2001; Van der tas, 1998, 1992 (dalam Cairns, et al., 2011). Penelitianpenelitian tersebut menginvestigasi harmonisasi akuntansi namun ketika belum terjadi adopsi IFRS. Penelitian tersebut menyebutkan bahwa jika standar akuntansi bervariasi, dalam artian tidak ada satu standar akuntansi yang sama untuk negara-negara di Eropa, maka akan mengakibatkan variasi dalam memilih kebijakan akuntansi sehingga berdampak pada tingkat daya banding laporan keuangan.

Konsep penelitian harmonisasi tersebut kemudian oleh Cairns et al. (2011) digunakan dalam menginvestigasi penerapan nilai wajar dan kebijakan akuntansi perusahaanperusahaan di UK dan Australia.Cairns et al. menggunakan T-Index yang dikembangkan oleh Taplin (2004, 2010, 2011).Kemudian dengan indeks tersebut digunakan untuk menilai tingkat daya banding laporan keuangan atas penerapan pengukuran nilai wajar oleh perusahaan-perusahaan di UK dan Australia.

Untuk pengukuran daya banding, Cairns et al. (2011) telah meneliti dampak aturan pengukuran nilai wajar atas daya banding laporan keuangan di Australia dan UK. Penelitian Cairns ini dapat diteliti kembali karena penelitian Cairns et al. menginvestigasi perusahaan-perusahaan di negara maju yang berdampak pada keterbukaan infomasi pasar.Selainitu, proses adopsi IFRS di UK dan Australia berbeda dengan Indonesia yang melakukan secara bertahap. Hal tersebut tentunya akan membawa dampak yang berbeda untuk perusahaan di Indonesia serta menyebabkan hasil di UK dan Australia, tidak bisa digeneralisasi untuk negara yang menerapkan IFRS secara bertahap.

Adopsi IFRS di Indonesia berbeda dengan UK dan Australia yang semua peraturan akun mengalami masa transisi yang sama. Di Indonesia, standar pengukuran nilai wajar pertama baru berlaku efektif per 1 Januari 2008 yaitu untuk PSAK 13 tentang
Properti Investasi dan PSAK 16 tentangAset Tetap. Kemudian tahun-tahun berikutnya disusul oleh standar lain. Kedua PSAK tersebut bersifat pilihan dalam pengukuran nilai wajar. Sebenarnya PSAK 55 tentang Instrumen Keuangan: Pengakuan dan Pengukuran sudah lebih dahulu disahkan, namun efektif berlaku baru dimulai per1 Januari 2010 (mengalami penundaan berlaku efektif yang awalnya per 1 Januari 2009). Dalam instrumen keuangan ini, ada yang bersifat pilihan dan wajib dalam menerapkan pengukuran nilai wajar.

Penelitian ini juga berbeda dengan Cairns et al. dalam sampel.Tujuan utama Cairns memang melihat dampak pengukuran nilai wajar atas daya banding laporan keuangan baik secara nasional maupun internasional, maka dari itu minimal harus mengambil sampel dua negara.Penelitian ini lebih fokus menginvestigasi dampak pengukuran nilai wajar atas daya banding laporan keuangan pada satu negara yang mengadopsi IFRS secara bertahap.

Tujuan dari penelitian ini adalah ingin menginvestigasi pengukuran nilai wajar dan dampaknya terhadap kebijakan akuntansi dan tingkat daya banding laporan keuangan di Indonesia, dengan rincian tujuan khusus yaitu (1) Membuktikan bahwa penerapan pengukuran nilai wajar PSAK-Konvergensi IFRS yang diwajibkan (mandatory) secara signifikan dapat meningkatkan daya banding laporan keuangan (2) Membuktikan bahwa penerapan pengukuran nilai wajar PSAKKonvergensi IFRS yang diperbolehkan memilih (optional) dapat menurunkan daya banding laporan keuangan

Penelitian ini merupakan penelitian yang pertama di Indonesia yang menginvestigasi pengukuran nilai wajar dari sisi daya banding dengan menggunakan indeks Taplin.Penelitian ini diharapkan dapat memberikan masukan sebagai bahan pertimbangan kepada Dewan Standar untuk aturan pengukuran nilai wajar terkait daya banding ketika awal pelaksanaan. Dari sisi literature, penelitian ini diharapkan menjadi rujukan penelitian selanjutnya serta 
memperkenalkan indeks-T sebagai salah satu pengukuran daya banding.

\section{KAJIAN LITERATUR}

\section{Pengukuran Nilai Wajar}

Dalam PSAK 13 (Revisi 2007), definisi nilai wajar adalah "suatu jumlah yang digunakan untuk mengukur aset yang dipertukarkan melalui suatu transaksi yang wajar (arm's length transaction) yang melibatkan pihak-pihak yang berkeinginan dan memiliki pengetahuan yang memadai" (Paragraf 5, PSAK 13 (revisi (2007)). Definisi yang sama juga tertera dalam PSAK 16 (Revisi 2007) serta PSAK 55 (Revisi 2006).

Dalam standar akuntansi keuangan sesuai denganPedoman Standar Akuntansi Keuangan (PSAK) 55, konsep nilai ini memiliki tiga hierarki, yaitu (1) quoted proces at active markets, (2) no actives market, valuation techniques, dan (3) no market equities cost. Hirarki tersebut dipertegas dalam PSAK 68 tentang pengukuran nilai wajar.

\section{Kebijakan Akuntansi di Indonesia PSAK 13 Properti Investasi}

PSAK 13 (Revisi 2007) tentangProperti Investasi disahkan oleh Dewan Standar Akuntansi Keuangan (DSAK) pada tanggal 29 Mei 2007 dan berlaku efektif per 1 Januari 2008. PSAK 13 (revisi 2007) menggantikan PSAK 13 tentang Akuntansi Investasi (2004) dan mengadopsi Internasional Accounting Standard (IAS) 40 sebagai langkah konvergensi IFRS.

Properti investasi pada awal diukur berdasarkan biaya perolehannya, termasuk juga biaya transaksi (paragraf 20).Pengukuran setelah pengakuan dan berlaku untuk seluruh aset properti investasi adalah memilih model nilai wajar atau model biaya sebagai kebijakan akuntansinya.Nilai wajar yang diterapkan tidak disertai melakukan depresiasi. Sedangkan metode biayamenggunakan nilai cost dengan melakukan depresiasi, kecuali jika properti tersebut memenuhi kriteria untuk dijual.

\section{PSAK 16 Aset Tetap}

PSAK 16 (revisi 2007 menggantikan PSAK 16 (1994) tentang Aktiva Tetap dan Aktiva Lain-lain dan PSAK No. 17 (1994) tentang Akuntansi Penyusutan dan berlaku efektif per 1 Januari 2008.PSAK ini disahkan bersamaan dengan PSAK 13 tentang Properti investasi, yaitu 29 Mei 2007. PSAK 16 (revisi 2007) mengadopsi IAS 16 (2003) tentang Property, Plant, and Equipment.Terdapat perubahan dari pengukuran hanya model biaya saja menjadi pilihan dua metode pengukuran, yaitu nilai revaluasian atau model biaya.

Pada saat aset berwujud diterima diakui berdasarkan harga perolehan. Sedangkan pengakuan setelah pengakuan awal dengan memilih menggunakan model biaya atau revaluasi untuk seluruh aset tetap dalam kelompok yang sama (paragraf 29). Model biaya berarti setelah pengakuan sebagai aset dicatat pada biaya perolehan dikurangi dengan akumulasi penyusutan dan akumulasi rugi penurunan nilai (paragraf 30). Untuk model revaluasi, aset diukur secara andal dicatat pada jumlah revaluasian, yaitu nilai wajar pada tanggal revaluasi dikurangi akumulasi penyusutan dan akumulasi rugi penurunan nilai setelah tanggal revaluasi (paragraf 31 ).

\section{PSAK 19 Aset Tak berwujud}

PSAK 19 (Aset 2010) merupakan pengganti dari PSAK 19 (2000) yang efektif dimulai pada 1 Januari 2011 dengan penerapan prospektif. PSAK 19 (revisi 2010) mengemukakan bahwa aset tak berwujud pada awalnya diakui sebesar biaya perolehan (paragraf 24). Sedangkan pengukuran setelah tanggal pengakuan adalah memilih dengan menggunakan model biaya atau model revaluasi (paragraf 72). Model biaya melaporkan biaya perolehan dikurangi akumulasi amortisasi dan akumulasi rugi penurunan nilai. Sedangkan model revaluasi menggunakan nilai wajar pada tanggal revaluasi dikurangi akumulasi amortisasi dan akumulasi rugi penurunan nilai setelah tanggal revaluasi. Pengukuran nilai wajar dapat dilakukan jika referensi pasar aktif dapat ditentukan (paragraf 75). 


\section{PSAK 55, Instrumen Keuangan: Pengakuan dan Pengukuran}

Setidaknya ada 3 PSAK yang terkait dengan instrumen keuangan, yaitu 50, 55 dan 60. Namun karena penelitian ini lebih fokus pada pengukuran maka menggunakan PSAK 55 (revisi 2006) yang mangadopsi IAS 39. PSAK 55 (revisi 2006) merupakan PSAK pertama yang mengatur tentang nilai wajar.Awalnya penerapan PSAK tersebut efektif per 1 Januari 2009.Namun, karena ketidaksiapan industri, khususnya bank dan keuangan lainnya, maka mundur menjadi per 1 Januari 2010.PSAK ini mengalami revisi kembali pada tahun 2011 menjadi PSAK 55 (revisi 2011). Perusahaan yang menerapkan PSAK 55 (revisi 2011) secara prospektif per 1 Januari 2012 dengan penerapan dini diizinkan. Dalam penelitian ini masih menggunakan PSAK 55 (revisi 2006), karena yang mengatur penerapan pengukuran nilai wajar.

Dari PSAK ini diketahui bahwa instrumen keuangan dibagi menjadi 4, yaitu aset atau liabilitas keuangan yang diukur pada nilai wajar melalui laba rugi, investasi dimiliki hingga jatuh tempo, pinjaman yang diberikan dan piutang, serta aset keuangan tersedia untuk dijual. Pengukuran untuk instrumen keuangan ada dua mekanisme, menggunaan nilai wajar dan biaya amortisasi. Kategori instrumen keuangan berupa aset atau liabilitas keuangan yang diukur pada nilai wajar melalui laba rugi dan aset keuangan tersedia untuk dijual menggunakan pengukuran nilai wajar, dan menggunakan nilai amortisasi untuk investasi yang dimiliki hingga jatuh tempo dan pinjaman yang diberikan dan piutang.

\section{Daya Banding (Comparability)}

Karakteristik kualitatif laporan keuangan sebagaimana yang terdapat di KDPPLK adalah relevan, andal, dapat dipahami dan dapat diperbandingkan. Standar mengemukakan bahwa implikasi penting dari dapat diperbandingkan adalah pengguna harus mendapat informasi tentang kebijakan akuntansi yang digunakan dalam penyusunan laporan keuangan dan perubahan kebijakan serta pengaruh atas perubahan tersebut. Ketaatan pada standar akuntansi keuangan termasuk pengungkapan membantu tercapainya daya banding (KDPPLK, paragraf 40). Daya banding ini memudahkan pengguna informasi laporan keuangan untuk membandingkan perusahaan satu dengan lainnya atau kinerja perusahaan sekarang dengan sebelumnya.

DeFranco, et al. (2011) mengemukakan bahwa belum ada pengukuran yang spesifik mengenai daya banding. Padahal para peneliti, akademisi, dan penyusun laporan dan penyusun standar sangat memperhatikan daya banding. FASB (1980 dalam DeFranco, et al. (2011) mendefisinikan bahwa "comparability is the quality of information that enables users to identify similarities and differences between two sets of economic phenomena."Kemudian dari definisi tersebut DeFranco et al. (2011) memodelkan Persamaan yang berarti bahwa laporan keuangan suatu perusahaan merupakan fungsi dari kejadian-kejadian ekonomis dan akuntansi atas kejadian tersebut. Persamaan tersebut adalah sebagai berikut:

\section{Financial Statementsi $=$ fi $($ Economic Eventsi)}

Model yang dikembangkan oleh De Franco et al. (2011) mengukur tingkat daya banding dengan mengukur angka-angka akuntansi. Untuk melakukan harmonisasi IFRS, Catuogno dan Allini (2011) menguji tingkat daya banding laporan keuangan di Itali dan Spanyol dengan menggunakan indeks Van Der C Tas Index untuk mengukur tingkat daya banding. Indeks tersebut mengukur daya banding perusahaan yang menerapkan beberapa metode akuntansi yang berbeda.

Penelitian Cairns et al. (2011) menggunakan pendekatan yang hampir sama dengan Catuogno dan Allini (2011) untuk mengukur daya banding laporan keuangan sebagai dampak diberlakukannya standar pengukuran nilai wajar IFRS. Cairns et al. (2011) menggunakan indeks Taplin yang mengukur probabilitas daya banding laporan keuangan perusahaan atas penerapan suatu metode akuntansi.Dengan menggunakan 
indeks Taplin memungkinkan melakukan investigasi daya banding laporan keuangan antar negara (Taplin, 2004, 2010).Pengembangan indeks Taplin (2004) juga berasal dari indeks Van Der C Tasyang digunakan oleh Catuogno dan Allini (2011).

Taplin (2004) mengembangkan indeks untuk mengukur daya banding dalam rangka harmonisasi laporan keuangan.Indeks tersebut kemudian dikembangkan untuk pengukuran daya banding laporan keuangan perusahaanperusahaan yang mengadopsi atau konvergensi IFRS.Hasil pengembangan indeks Taplin yang membedakan dengan indeks harmonisasi sebelumnya adalah indeks Taplin dapat membandingkan laporan keuangan secara internasional. Berikut adalah formula indeks Taplin:

$$
T=\sum_{i=1}^{N} \sum_{j=1}^{N} \sum_{k=1}^{M} \sum_{l=1}^{M} \alpha_{k l} \beta_{i j} P_{k i} P_{l j}
$$

Keterangan:

$\alpha_{k l}=$ Koefisien daya banding antara metode akuntansi $\mathrm{k}$ dan 1

$\beta_{i j}=$ Pembobotan perbandingan antara perusahaan-perusahaan di perusahaan $\mathrm{i}$ dan $\mathrm{j}$

$P_{k i}=$ Proporsi perusahaan-perusaahaan di negara i yang menerapkan metode akuntansi $\mathrm{k}$

$P_{l j}=$ Proporsi perusahaan-perusaahaan di negara $\mathrm{j}$ yang menerapkan metode akuntansi 1

$\mathrm{N}=$ menunjukkan jumlah negara yang diobservasi

$\mathbf{M}=$ menunjukkan jumlah pilihan metode akuntansi yang diteliti

Dari formula di atas menunjukkan pembobotan dan proporsi jika mengukur daya banding secara internasional.Indeks Taplin (2010) melengkapi indeks-T dengan mendesain formula untuk menghitung Standard Error (SE) dan signifikan p-value.

Barth, et al. (2012) melakukan investigasi daya banding dengan cara yang berbeda, yaitu menggunakan matrik daya banding dari angka akuntansi. Barth, et al. menyebutkan bahwa perusahaan yang menerapkan IFRS mempunyai daya banding sistem akuntansi dan nilai relevan yang lebih tinggi dibandingkan perusahaan US yang menggunakan standar domestik. Barth, et al. juga menambahkan bahwa tingkat daya banding yang tinggi untuk perusahaan yang mengadopsi IFRS secara mandatory, perusahaan dengan tekanan dan hukum yang tinggi dan dalam beberapa tahun terakhir.

De Franco, et al. (2011) mengatakan bahwa daya banding lebih tinggi untuk perusahaan dengan industri sama dan dalam kondisi pasar yang serupa. Dikemukakan juga bahwa daya banding lebih tinggi untuk perusahaan yang memiliki atribut laba serupa seperti kualitas akrual, prediktibilitas laba, perataan laba dan apakah ada perusahaan yang melaporkan kerugian.

Callao, et al. (2007) mengemukakan dalam hasil penelitian yang dilakukan di Spanyol bahwa buruknya tingkat daya banding dikarenakan penggunaan IFRS dan standar lokal dalam waktu dan tempat yang sama. Dengan demikian tingkat nilai relevansi juga menurun karena gap antara nilai buku dan nilai pasar lebih luas setelah pengimplementasian IFRS.

\section{Perumusan Hipotesis}

Cairns, et al. (2011) meneliti pengukuran nilai wajar wajib di Australia dan UK dan menemukan bahwa kebijakan akuntansi berupa Instrumen Keuangan Diperdagangkan dan Instrumen Keuangan Tersedia Dijual (IAS 39), Pembayaran Berbasis Saham (IFRS 2)serta Aset Biologis (IAS 41). Dalam penelitian tersebut terbukti bahwa diwajibkannya pengukuran nilai wajar dapat meningkatkan daya banding, kecuali untuk Aset Biologis yang tidak berdampak signifikan.Di Indonesia, PSAK-Revisi konvergensi IFRS mewajibkanpengukuran nilai wajar untuk beberapa kebijakan akuntansi seperti PSAK 55 Instrumen Keuangan: Pengakuan dan Pengukuran, spesifik untuk kategori aset atau liabilitas keuangan yang diukur pada nilai wajar melalui laba rugi dan aset keuangan tersedia untuk dijual. Adanya kewajiban pengukuran nilai wajar (tanpa opsi/pilihan) untuk kebijakan akuntansi instrumen keuangan mengharuskan perusahaan menerapkan nilai 
wajar. Hal tersebut harus dipatuhi karena jika tidak akan ada sanksi berupa opini audit jika tidak sesuai dengan standar akuntansi keuangan. Jika semua perusahaan mematuhi dan sesuai dengan standar yang sama dalam suatu metode pengukuran, maka kewajiban standar pengukuran tersebut dapat meningkatkan daya banding, sehingga hipotesis yang diajukan dalam penelitian ini adalah:

\section{H1: Kewajiban pengukuran nilai wajar PSAK-Konvergensi IFRS meningkatkan daya banding laporan keuangan perusahaan di Indonesia}

Adanya pilihan kebijakan akuntansi memungkinkan perbedaan bentuk laporan keuangan sehingga dapat kehilangan tingkat daya banding. Parker dan Morris(2001) menemukan bahwa daya banding laporan keuangan perusahaan perusahaan di UK dan Australia hanya terjadi pada tiga kebijakan akuntansi. Sedangkan daya banding laporan keuangan antar perusahaan di UK terjadi pada tujuh kebijakan akuntansi dan di Australia terjadi padalima kebijakan akuntansi. Tingkat daya banding yang relatifrendah, tidak terlepas dari perbedaan metode pengukuran.Sedangkan penerapan suatu metode tergantung pada adanya insentif yang akan diterima oleh perusahaan (Christensen dan Nikoleav, 2009). Field, et al. (2001) juga menyebutkan bahwa perusahaan akan menyeleksi kebijakan akuntansi berdasarkan insentif yang diterima. Cairns, et al. (2011) menemukan perusahaan yang menerapkan nilai wajar masih relatif rendah ketika standar tidak mewajibkan, kecuali untuk properti investasi sudah banyak disajikan dengan menggunakan pengukuran nilai wajar.PSAK konvergensi IFRS memberikan pilihan metode pengukuran untuk beberapa kebijakan akuntansi seperti dalam properti investasi, aset tetap, aset tak berwujud, instrumen keuangan dimilliki hingga jatuh tempo, serta piutang dan pinjaman yang diberikan. Ketika perusahaan diperbolehkan untuk memilih metode pengukuran metode biaya atau nilai wajar untuk akun-akun tersebut maka memungkinkan ada reaksi yang berbeda dari perusahaan sesuai dengan kepentingan masing-masing perusahaan sehingga akan dapat menurunkan tingkat daya banding. Dengan demikian rumusan masalah kedua yang diajukan adalah sebagai berikut:

H2: Pilihan pengukuran nilai wajar PSAKKonvergensi IFRS menurunkan daya banding laporan keuangan perusahaan di Indonesia

\section{METODOLOGI PENELITIAN}

Penelitian ini merupaka penelitian kuantitatif yang diawali dengan analisa konten dari laporan keuangan perusahaan untuk menentukan pilihan metode pengukuran.Dari hasil analisa konten dilakukan penghitungan tingkat daya banding dengan menggunakan indeks Taplin. Pengujian hipotesis dilakukan dengan uji beda yang membandingkan antara metode yang dipilih sebelum dan setelah penerapan standar baru.

Fokus dalam penelitian ini adalah pengukuran nilai wajar pada kebijakan pilihan akuntansi.Variabel kebijakan akuntansi yang akan dianalisis dalam penelitian ini adalah kebijakan pengukuran metode biaya atau nilai wajar untuk Properti Investasi (PSAK 13 Revisi 2007), Aset Tetap (PSAK 16 Revisi 2007), Aset Takberwujud (PSAK 19 Revisi 2010), dan Instrumen Keuangan (PSAK 55 Revisi 2006).

Kemudian, penelitian ini menguji Daya Banding yang digunakan untuk menginvestigasi masing-masing kebijakan akuntansi sebagai akibat/dampak dari aturan pengukuran nilai wajar.Pengukuran yang digunakan untuk menilai tingkat daya banding dengan menggunakanIndeks- $\mathrm{T}$, merupakan pendekatan yang dikembangkan oleh Taplin. Indeks- $T$ merupakan pendekatan yang mengukur daya banding dengan menilai jumlah perusahaan yang menerapkan dan perusahaan yang tidak menerapkan pengukuran nilai wajar.Perusahaan yang menerapkan kebijakan yang sama akan dianggap mempunyai daya banding karena probabilitas penggunaan metode yang sama (Taplin, 2004). Indeks-T ini tidak melihat 
angka akuntansi dalam menentukan daya banding antar laporan keuangan perusahaan.

Sampel penelitian diambil dengan menggunakan nonprobability sampling, yaitu dipilih berdasarkan subjektifitas tertentu dan tidak mengikuti pola atau suatu skema (Cooper \& Schindler, 2011). Non probability yang digunakan adalah dengan purposive sampling. Sampel diambil dari perusahaanperusahaan yang terdaftar di Bursa Efek Indonesia (BEI) pada masa sebelum dan ketika PSAK baru-konvergensi IFRS berlaku efektif.

Perusahaan jasa keuangan dikeluarkan dari sampel karena mempunyai peraturan tersendiri yang lebih spesifik, terutama terkait dengan instrumen keuangan yang menggunakan pengukuran nilai wajar. Kemudian sampel perusahaan adalah yang terdaftar di BEI non keuangan tahun 2007 dan 2008 untuk pengukuran nilai wajar aset properti investasi dan aset tetap, tahun 2010 dan 2011 untuk pengukuran nilai wajar aset tak berwujud, serta tahun 2009 dan 2010 untuk instrumen keuangan.

\section{Tahapan Analisa Data}

Tahap pertama, dilakukan analisa konten yang dilakukan pada masing-masing akun dalam penelitian ini yang meliputi sebelum dan setelah penerapan PSAK.Hasil analisa konten akan diberikan skor antara 0 s.d. 1 untuk mencatat kebijakan yang digunakan setiap tahunnya. Skor 0 jika perusahaan menggunakan metode biaya dan 1 jika menggunakan pengukuran nilai wajar.

Untuk PSAK 13, 16 dan 19, pilihan metode pengukuran dikategorikan ke dalam tiga pilihan yaitu "Metode Biaya", "Deemed Cost", dan "Nilai Wajar"/"Revaluasi. Jika perusahaan sebelumnya menggunakan nilai wajar dan beralih ke metode biaya maka perusahaan memberlakukan deemed cost ${ }^{l}$.

PSAK 55 (2006) membagi instrumen keuangan menjadi empat kelompok, yaitu instrumen keuangan dinilai dengan nilai wajar

\footnotetext{
${ }^{1}$ Deemed cost adalah nilai revaluasian atau nilai wajar yang dianggap sebagai biaya perolehan ketika terjadi perubahan dari metode revaluasi/nilai wajar ke metode biaya
}

melalui laba dan rugi (diperdagangkan), tersedia dijual, dimiliki hingga jatuh tempo serta piutang dan pinjaman yang diberikan.Dua kelompok pertama tersebut diharuskan meng-gunakan nilai wajar dan dua kelompok terakhir diperbolehkan memilih metode pengukuran. Masing-masing kebijakan akuntansi untuk instrumen keuangan akandikategorikan ke dalam dua kategori yaitu: "Metode Biaya" dan "Nilai Wajar".

Tahap kedua, melakukan perhitungan daya banding dengan perhitungan IndeksT.Untuk menginvestigasi tingkat daya banding akun-akun yang diteliti, hasil analisa konten dilakukan penghitungan indeksT.Penelitian ini menggunakan indeks-T yang dikembangkan oleh Taplin (2004). Indeks Taplin dikembangkan untuk daya banding antar perusahaan dalam suatu negara dan dapat juga diterapkan untuk antar negara. Namun dalam penelitian ini akan digunakan indeks Taplin yang menganalisa daya banding perusahaan dalam satu negara. Sehingga dalam penelitian ini tidak menggunakan semua kerangka indeks-T.

Perhitungan indeks Taplin untuk satu negara sebagaimana tercantum dalam tabel 3a. Misalnya tahun ke-1, dari hasil analisa konten didapatkan hasil yang menerapkan Metode A sebanyak 60 perusahaan dan Metode B sebanyak 40 perusahaan (total 100 perusahaan). Maka perhitungan Indeks Taplin adalah kuadrat dari persentasi penerapan metode A ditambah dengan kuadrat dari persentasi metode B. Sehingga nilai indeks Taplin untuk tahun ke-1 adalah sebesar 0.52 yang didapatkan dari hasil $(40 / 100)^{2}+$ $(60 / 100)^{2}$. Nilai 0.52 menunjukkan tingkat probabilitas daya banding antar laporan keuangan sebesar 0.52 yang menunjukkan tingkat daya banding di nilai tengah karena semakin mendekati 1 semakin tinggi daya banding laporan keuangan perusahaan. Sehingga jika dilihat dari tabel $3 \mathrm{a}$ daya banding tahun ke-2 lebih tinggi dari daya banding tahun ke-1.Daya banding tahun ke-2 menunjukkan angka 1.00 yang menunjukkan daya banding sangat tinggi (tingkat daya banding yang mutlak) sehingga 
probabilitasnya 100\%.Dalam contoh ke-2

memiliki.

sebagaimana tabel di bawah ini, yaitu tahun

Tabel 1. Contoh Perhitungan Indeks-T untuk Satu Negara

\begin{tabular}{lccc}
\hline & Metode A & Metode B & T-Index (National) \\
\hline Tahun ke-1 & 60 & 40 & 0.52 \\
Tahun ke-2 & 100 & 0 & 1.00 \\
\hline
\end{tabular}

Tahap Ketiga, dilakukan pengujian hipotesis dengan menggunakan uji beda dengan dua sampel berhubungan (2 related samples). Dalam penelitian ini digunakan $\mathrm{Uji} \mathrm{Mc}$ Nemar atau juga Uji Wilcoxon untuk menentukan signifikansi apakah terdapat penurunan atau peningkatan daya banding sebelum dan setelah implementasi PSAKkonvergensi IFRS.

HASIL DAN PEMBAHASAN
Perusahaan yang diteliti adalah semua yang terdaftar di BEI sebanyak 502 perusahaan dikurangi dengan sektor keuangan sebanyak 77 perusahaan. Namun, data laporan tahunan dari PDEB tidak semua mencantumkan laporan keuangan dan atau catatan atas laporan keuangan sehingga sampel dikurangi dengan persahaan yang tidak lengkap datanya.Tabel 4.1 berikut menjelaskan jumlah perusahaan yang diteliti sesuai dengan teknik sampling yang dipaparkan di bab 2 .

Tabel 2. Jumlah Sampel Penelitian

\begin{tabular}{|c|c|c|c|c|}
\hline & & $\begin{array}{c}\text { Properti } \\
\text { Investasi dan } \\
\text { Aset Tetap } \\
\text { (tahun 2007 dan } \\
\text { 2008) }\end{array}$ & $\begin{array}{c}\text { Instrumen } \\
\text { Keuangan } \\
\text { (tahun 2009 dan } \\
\text { 2010) }\end{array}$ & $\begin{array}{c}\text { Aset } \\
\text { Takberwujud } \\
\text { (tahun 2010 dan } \\
\text { 2011) }\end{array}$ \\
\hline 1 & Perusahaan terdaftar di BEI & 502 & 502 & 502 \\
\hline 2 & Perusahaan sektor keuangan & 77 & 77 & 77 \\
\hline \multirow[t]{2}{*}{3} & $\begin{array}{l}\text { Laporan keuangan tidak ada } \\
\text { dan tidak lengkap }\end{array}$ & 123 & 180 & 161 \\
\hline & Total Sampel & 302 & 245 & 264 \\
\hline
\end{tabular}

Tabel 4.2 di bawah ini menunjukkan jumlah dan persentase hasil content analysis pengukuran nilai wajar pada beberapa kebijakan akuntansi baik yang diwajibkan atau yang diperbolehkan memilih. 


\begin{tabular}{|c|c|c|c|c|}
\hline & \multicolumn{2}{|c|}{$\begin{array}{c}\text { Sebelum } \\
\text { Konvergensi }\end{array}$} & \multicolumn{2}{|c|}{$\begin{array}{c}\text { Setelah } \\
\text { Konvergensi }\end{array}$} \\
\hline & $\mathbf{N}$ & $\%$ & $\mathbf{N}$ & $\%$ \\
\hline \multicolumn{5}{|l|}{ PSAK 13 Properti Investasi } \\
\hline Properti Investasi - Metode Biaya & 42 & $13.91 \%$ & 42 & $13.95 \%$ \\
\hline Properti Investasi - Deemed Cost & 0 & $0.00 \%$ & 0 & $0.00 \%$ \\
\hline Properti Investasi - Nilai Wajar & 1 & $0.33 \%$ & 3 & $1.00 \%$ \\
\hline NA & 259 & $85.76 \%$ & 256 & $85.05 \%$ \\
\hline $\begin{array}{c}\text { Total Perusahaan } \\
\text { PSAK 16 Aset Tetap }\end{array}$ & 302 & & & \\
\hline Aset Tetap - Metode Biaya & 262 & $86.75 \%$ & 275 & $91.06 \%$ \\
\hline Aset Tetap - Deemed Cost & 0 & $0.00 \%$ & 25 & $8.28 \%$ \\
\hline Aset Tetap - Revaluasi & 40 & $13.25 \%$ & 2 & $0.66 \%$ \\
\hline NA & 0 & $0.00 \%$ & 0 & $0.00 \%$ \\
\hline $\begin{array}{c}\text { Total Perusahaan } \\
\text { PSAK 19 Aset Takberwujud }\end{array}$ & \multicolumn{3}{|c|}{ PSAK 19 Aset Takberwujud } & \\
\hline Aset Takberwujud - Metode Biaya & 39 & $14.77 \%$ & 39 & $14.77 \%$ \\
\hline Aset Takberwujud - Deemed Cost & 0 & $0.00 \%$ & 0 & $0.00 \%$ \\
\hline Aset Takberwujud - Nilai Wajar & 0 & $0.00 \%$ & 0 & $0.00 \%$ \\
\hline NA & 225 & $85.23 \%$ & 225 & $85.23 \%$ \\
\hline \multicolumn{5}{|l|}{ PSAK 55 Instrumen Keuangan } \\
\hline$\overline{\text { Diperdagangkan - Metode Biaya }}$ & 0 & $0.00 \%$ & 0 & $0.00 \%$ \\
\hline Diperdagangkan - Nilai Wajar & 21 & $8.57 \%$ & 22 & $8.98 \%$ \\
\hline NA & 224 & $91.43 \%$ & 223 & $91.02 \%$ \\
\hline Total Perusahaan & 245 & & & \\
\hline Tersedia untuk Dijual - Metode Biaya & 4 & $1.63 \%$ & 4 & $1.63 \%$ \\
\hline Tersedia untuk Dijual - Nilai Wajar & 58 & $23.67 \%$ & 52 & $21.22 \%$ \\
\hline NA & 183 & $74.69 \%$ & 189 & $77.14 \%$ \\
\hline Total Perusahaan & 245 & & & \\
\hline Dimiliki Hingga Jatuh Tempo-Metode Biaya & 24 & $9.80 \%$ & 24 & $9.80 \%$ \\
\hline Dimiliki Hingga Jatuh Tempo-Nilai Wajar & 1 & $0.41 \%$ & 0 & $0.00 \%$ \\
\hline NA & 220 & $89.80 \%$ & 221 & $90.20 \%$ \\
\hline Total Perusahaan & 245 & & & \\
\hline Aset Keuangan Lainnya-Metode Biaya & 245 & $100.00 \%$ & 245 & $100.00 \%$ \\
\hline Aset Keuangan Lainnya-Nilai Wajar & 0 & $0.00 \%$ & 0 & $0.00 \%$ \\
\hline NA & 0 & $0.00 \%$ & 0 & $0.00 \%$ \\
\hline Total Perusahaan & 245 & & & \\
\hline Aset Kewajiban Lainnya-Metode Biaya & 245 & $100.00 \%$ & 245 & $100.00 \%$ \\
\hline Aset Kewajiban Lainnya-Nilai Wajar & 0 & $0.00 \%$ & 0 & $0.00 \%$ \\
\hline NA & 0 & $0.00 \%$ & 0 & $0.00 \%$ \\
\hline Total Perusahaan & 245 & & & \\
\hline
\end{tabular}

Untuk laporan keuangan per 2007 dan 2008 terdapat data 302 perusahaan yang digunakan untuk menilai daya banding laporan keuangan atas kebijakan akuntansi pengukuran properti investasi dan aset tetap. Dari 302 perusahaan terdapat 43 dan 45, 
masing-masing untuk tahun 2007 dan 2008, yang mempunyai aset properti investasi. Sedangkan untuk aset tetap semua perusahaan memiliki aset tetap.

Laporan keuangan tahun 2009 dan 2010 terdapat data 245 perusahaan, yang digunakan untuk menilai daya banding laporan keuangan atas kebijakan akuntansi pengukuran instrumen keuangan. Perusahaan yang mempunyai instrumen keuangan yang diperdagangkan sebanyak 21 perusahaan untuk tahun 2009 dan 22 untuk tahun 2010 dan untuk aset keuangan tersedia dijual 62 dan 56 untuk tahun 2009 dan tahun 2010. Sedangkan untuk perusahaan yang mempunyai instrumen keuangan dimiliki hingga jatuh tempo sebanyak 25 dan 24 untuk tahun 2009 dan tahun 2010. Akun terakhir, semua perusahaan mempunyai instrumen keuangan yang masuk ke kelompok piutang dan pinjaman yang diberikan

\section{Hasil dan Pembahasan Daya Banding Laporan Keuangan}

Ada empat kebijakan yang diteliti, yaitu PSAK 13 tentang Properti Investasi, PSAK 16 tentang Aset Tetap, PSAK 19 tentang Aset Takberwujud, dan PSAK 55 tentang Instrumen Keuangan: Pengakuan dan Pengukuran. Properti investasi, aset tetap, aset takberwujud mempunyai peraturan pengukuran dengan memberikan opsi untuk memilih apakah menggunakan nilai wajar/revaluasi atau metode biaya. Sedangkan Instrumen Keuangan dibedakan menjadi empat kategori dimana yang diberikan opsi pilihan adalah kategori pinjaman yang diberikan dan piutang dan investasi dimiliki hingga jatuh tempo, sedangkan investasi yang diukur pada nilai wajar melalui laba rugi (investasi di perdagangkan) dan aset keuangan tersedia untuk dijual harus menggunakan nilai wajar.

Tabel 4.3 menunjukkan hasil indeks Taplin serta Standar Error dan P-value untuk periode sebelum standar efektif berlaku dan periode diterapkan standar baru.Masingmasing standar mempunyai masa efektif yang berbeda.Hal ini yang membedakan dengan penelitian Cairns et al. (2011), karena adanya perbedaan sistem adopsi IFRS.

Tabel 4. Hasil Pengukuran Daya Banding

\begin{tabular}{lccccc}
\hline & $\begin{array}{c}\text { T-Sebelum } \\
\text { Konvergensi }\end{array}$ & SE & $\begin{array}{c}\text { T-Setelah } \\
\text { Konvergensi }\end{array}$ & SE & $\boldsymbol{p}$-Value \\
\hline Investment Property & 0.955 & 0.14907 & 0.876 & 0.25226 & 0.625 \\
Aset Tetap & 0.770 & 0.33812 & 0.987 & 0.08084 & 0.000 \\
Aset Takberwujud & 1.000 & 0.0000 & 1.000 & 0.0000 & 1.000 \\
Instrumen Keuangan & & & & & \\
Diperdagangkan & 1.000 & 0.0000 & 1.000 & 0.0000 & 1.000 \\
$\begin{array}{l}\text { Instrumen Keuangan } \\
\text { Tersedia untuk Dijual }\end{array}$ & 0.879 & 0.28774 & 0.867 & 0.25987 & 1.000 \\
Instrumen Keuangan & & & & & \\
Dimiliki Hingga Jatuh & & & & & \\
Tempo & 0.923 & 0.20412 & 1.000 & 0.0000 & 1.000 \\
Aset Keuangan Lainnya & 1.000 & 0.0000 & 1.000 & 0.0000 & 1.000 \\
Kewajiban Keuangan & & & & & \\
Lainnya & 1.000 & 0.0000 & 1.000 & 0.0000 & 1.000 \\
\hline
\end{tabular}




\section{Aset Properti Investasi}

Tabel 4.2 menyajikan jumlah dan persentase perusahaan yang menerapkan metode biaya atau nilai wajar dari keseluruhan perusahaan yang diteliti. Untuk tahun 2007 sebanyak $13.91 \%$ perusahaan yang menggunakan metode biaya dan meningkat di tahun 2008 dengan persentase sebesar $13.95 \%$. Adapun pengukuran nilai wajar masih kecil, yaitu $0.33 \%$ untuk tahun 2007 dan meningkat menjadi 1\% untuk tahun 2008.

Dari sampel penelitian ini, pada tahun 2007 terdapat 43 perusahaan dan satu diantaranya menggunakan nilai wajar. Sedangkan tahun 2008, tahun pertama penerapan PSAK 13, terdapat 45 perusahaan yang memiliki aset properti investasi dengan tiga perusahaan menggunakan nilai wajar dan sisanya masih menggunakan metode biaya. Tidak terdapat perusahaan yang menerapkan deemend cost.

Seperti yang disajikan pada tabel 4.3 di atas, bahwa tingkat daya banding laporan keuangan yang mempunyai aset properti investasi sebesar 0.955 untuk tahun 2007 dan 0.876 untuk tahun 2008. Terdapat penurunan nilai daya banding sebanyak 0.079 poin. Namun ketika diuji beda dengan menggunakan Uji Beda-Mc Nemar, didapatkan signifikan p-value sebesar 0.625 > $\alpha$ 0.025, maka terima $\mathrm{H}_{0}$ dan tolak $\mathrm{H}_{1}$. Sehingga tidak ada beda antara sebelum dan ketika masa konvergensi PSAK 13 atas daya banding laporan keuangan perusahaan di Indonesia yang memiliki aset properti investasi.

Hasil penelitian Cairns et al. (2011) menunjukkan hasil yang sama untuk perusahaan Australia. Namun perusahaan di UK malah mengalami penurunan daya banding dikarenakan perbedaan definisi properti investasi.Di Indonesia sendiri terdapat 3 perusahaan yang menggunakan dan menyajikan aset properti investasi dengan menggunakan nilai wajar.Belum banyaknya perusahaan yang menggunakan nilai wajar dimungkinkan karena pengukuran nilai wajar perlu biaya tinggi untuk mendatangkan appraisal.
Terkait dengan nilai wajar pada properti investasi Farahmitha dan Siregar (2014) melakukan penelitian faktor-faktor yang mempengaruhi perusahaan memilih pengukuran nilai wajar untuk aset properti investasi.Hasil penelitian menunjukkan bahwa semakin tinggi hutang perusahaan menyebabkan kecil kemungkinan perusahaan memilih metode nilai wajar.Selain itu, kecilnya perusahaan memilih metode nilai wajar juga disebabkan tingkat asimetri informasi perusahaan rendah.Farahmita dan Siregar (2014) juga menyatakan bahwa rendahnya perusahaan properti memilih nilai wajar dimungkinkan karena faktor pajak.

\section{Aset Tetap}

Aset Tetap meliputi properti berupa tanah dan bangunan serta peralatan dan aset tetap lainnya.Dalam penelitian, tidak sebagaimana Cairns et al (2011), aset tetap disatukan antara properti dan peralatan. Hal ini karena kecenderungan sama antara pengukuran properti dan peralatan di Indonesia (hasil content analysis).

Tabel 4.2 menyebutkan distribusi perusahaan yang menerapkan metode pengukuran untuk aset tetap.Semua perusahaan menunjukkan mempunyai aset tetap.Untuk tahun 2007 perusahaan yang megukur dengan menggunakan metode biaya sebesar $86.75 \%$ dan revaluasi sebesar 13.25\%.Pengukuran revaluasi pada tahun 2007 lebih disebabkan oleh adanya pemerintah untuk melakukan revaluasi terhadap aset-aset tertentu perusahaan. Adapun tahun 2007, pengukuran metode biaya mengalami peningkatan menjadi $91.06 \%$, sedangkan yang mengenakan deemed cost sebanyak $8.28 \%$ dan revaluasi hanya kecil sekali yaitu $0.66 \%$.

Berdasarkan indeks Taplin didapatkan hasil bahwa terdapat peningkatan daya banding laporan keuangan, yaitu 0.770 pada tahun 2007 menjadi 0.987 pada tahun 2008 . Penilaian indeks ini dengan mengasumsikan deemed cost sama dengan metode biaya, karena perusahaan yang melakukan penilaian deemed cost adalah perusahaan yang awalnya mengukur aset tetap dengan metode revaluasi 
dan selanjutnya metode biaya. Berdasarkan Uji Beda Mc Nemar didapatkan signifikansi $p$-value sebesar $0.000<\alpha, 0.025 \%$, maka tolak $\mathrm{H}_{0}$ dan terima $\mathrm{H}_{1}$ sehingga ada beda antara masa sebelum dan ketika konvergensi PSAK 16. Kenaikan indeks-T mengindikasikan bahwa terjadi peningkatan daya banding secara signifikan.

Terjadi peningkatan ini karena banyak perusahaan yang awalnya melakukan revaluasi untuk aset dan beberapa aset tertentu sesuai dengan ketentuan pemerintah, mengubah metode untuk menggunakan metode biaya.Kecenderungan ini terjadi secara hampir bersamaan.Hanya dua dari 302 perusahaan yang menggunakan nilai wajar ketika masa konvergensi dengan diterbitkannya PSAK 16. Hal ini sama dengan penelitian Cairns et al. (2011), bahwa terdapat peningkatan daya banding baik di UK maupun di Australia. Sebagaimana di UK dan Australia, perusahaan di Indonesia juga lebih banyak menggunakan metode biaya dibandingkan metode revaluasi.Hal ini karena menggunakan metode revaluasi menimbulkan biaya untuk melakukan appraisal dan penentuan sendiri diragukan keandalannya.

\section{Aset Takberwujud}

Dari sampel sebanyak 264 perusahaan, hanya 39 perusahaan yang mempunyai aset takberwujud.Semua perusahaan menggunakan metode biaya baik ketika tahun 2010 (sebelum PSAK konvergensi IFRS) maupun ketika tahun 2011, tahun efektif PSAK 19 (2010).Sehingga tingkat daya banding 1 yang menunjukkan bahwa daya banding laporan keuangan tinggi.Tidak ada perubahan dalam pengukuran aset Takberwujuddi Indonesia.

Hasil penelitian sama seperti halnya penelitian Cairns et al. baik untuk UK maupun Australia tidak ada perubahan daya banding sebelum dan sesudah penggunaan IFRS. Sebabnya juga sama karena semua perusahaan memilih menggunakan metode biaya. Penggunaan metode biaya ini dimungkinkan karena sulitnya menentukan keandalan nilai wajar dari aset takberwujud.

\section{Instrumen Keuangan}

Ada empat kategori instrumen keuangan sesuai dengan PSAK 55, dengan dua kategori (Instrumen diperdagangkan dan tersedia dijual) harus menggunakan pengukuran nilai wajar dan dua kategori (instrument dimiliki sampai jatuh tempo serta piutang dan pinjaman yang diberikan) memilih antara metode biaya dan nilai wajar.

\section{Instrument Keuangan diperdagangkan}

Untuk kategori pertama, instrumen diperdagangkan atau dalam PSAK 55 (2006) disebut sebagai aset atau kewajiban keuangan yang diukur pada nilai wajar melalui laporan laba rugi, pada tahun 2009 terdapat 21 dari 245 perusahaan sampel mempunyai aset tersebut dan mengukur dengan nilai wajar. Sedangkan tahun 2010 terdapat 22 perusahaan yang mempunyai aset tersebut dan mengukur pada nilai wajar.

Berdasarkan indeks Taplin didapat angka daya banding mutlak yaitu sebesar 1, baik untuk tahun 2009 maupun 2010.Hal ini karena semua perusahaan yang mempunyai instrumen keuangan yang diperdagangkan menggunakan nilai wajar. Sehingga Uji Beda Mc Nemar tidak dapat dilakukan karena tidak ada beda sama sekali (asumsi Mc Nemar harus dikomotus). Hal ini mengindikasikan bahwa memang tidak ada perubahan antara sebelum dan setelah aturan pengukuran nilai wajar.

Hasil ini sejalan dengan penelitian Cairns et al untuk perusahaan di Australia. Perusahaan UK mengalami kenaikan daya banding dan Cairns et al sendiri menyatakan bahwa kenaikan tersebut karena penggunaan nilai wajar awalnya hanya untuk perusahaan bank dan asuransi dan kini semua perusahaan. Tidak ada perubahan daya banding yang signifikan untuk Indonesia lebih dimungkinkan karena antara penerbitan PSAK 55 dengan masa efektifnya terjadi jeda waktu yang lama.Sehingga perusahaan sudah melakukan persiapan sebelumnya.Hasil juga menunjukkan bahwa semua perusahaan yang memiliki instrumen keuangan diperdagangkan mengukur dengan nilai wajar.Hal ini karena penentuan nilai wajar tersedia di pasar modal. 


\section{Instrumen keuangan tersedia untuk dijual}

Terdapat sebanyak 62 perusahaan yang memiliki instrumen keuangan yang tersedia dijual pada tahun 2009 dan 56 perusahaan pada tahun 2010.Berdasarkan tingkat persentase penggunan metode nilai wajar dibandingkan dengan total perusahaan sebanyak 23,67\% untuk tahun 2009 dan $21.22 \%$ untuk tahun 2010. Metode nilai wajar dipilih sebanyak $1.63 \%$ baik tahun 2009 maupun 2010. Baik pada tahun 2009 maupuun 2010 terdapat 4 perusahaan yang menggunakan metode biaya karena tidak dapat menentukan harga pasar secara andal di pasar, selebihnya menggunakan nilai wajar.

Berdasarkan indeks- $T$, hasil penelitian menunjukkan bahwa tingkat daya banding instumen keuangan tersedia dijual tinggi yaitu 0.879 pada tahun 2009 dan 0.867 pada tahun 2010. Sedikit penurunan yang terjadi $(0.012$ poin) karena pada tahun 2009 jumlah perusahaan yang memiliki instrumen tersebut lebih sedikit dibandingkan tahun 2009. Uji hipotesis menunjukkan nilai signifikansi nilai p-value sebesar $1.000>\alpha \quad 0.025$ yang menunjukkan terima $\mathrm{H}_{1}$ dan tolak $\mathrm{H}_{0}$, yang artinya bahwa tidak ada beda sebelum dan ketika penerapan PSAK 55 untuk instrumenkeuangan tersedia dijual.

Hasil penelitian menunjukkan hal yang sama untuk penelitan Cairns et al untuk daya banding perusahaan di UK, bahwa ada perubahan signifikan. Namun, daya banding perusahaan Australia menunjukkan kenaikan daya banding signifikan.Perusahaan di UK masih sama dengan perusahaan di Indonesia yaitu masih ada yang menggunakan metode biaya setelah berlaku adopsi IFRS. Sedangkan perusahaan Australia semua perusahaan menggunakan nilai wajar.Meskipun demikian, daya banding laporan keuangan di Indonesia tinggi.

\section{Instrumen Keuangan Dimiliki Sampai Jatuh Tempo}

Terdapat 25 perusahaan pada tahun 2009 dan 24 perusahaan pada tahun 2010 yang memiliki instrumen keuangan dimiliki hingga jatuh tempo dari 245 sampel perusahaan. Pada tahun 2009 ada 1 perusahaan yang menggunakan nilai wajar dan pada tahun 2010 tidak ada perusahaan yang menggunakan nilai wajar. Perusahaan lebih memilih menggunakan metode biaya untuk mengukur instrumen keuangan dimiliki hingga jatuh tempo.

Berdasarkan indeks- $\mathrm{T}$, karena ada satu perusahaan yang menggunakan nilai wajar maka poin indeks sebesar 0.923, dan meningkat menjadi 1.000 pada tahun 2010.Peningkatan tersebut juga sangat kecil karena hanya pengaruh satu perusahaan saja, yaitu sebesar 0.077 . berdasarkan Uji beda Mc Nemar dihasilkan signifikansi P-value sebesar $1.000>\alpha 0.025$, sehingga terima $\mathrm{H} 1$ dan tolak H0 yang artinya tidak ada perbedaan signifikan sebelum dan ketika penerapan PSAK 55 untuk instrumen keuangan yang dimiliki hingga jatuh tempo.

\section{Piutang dan Pinjaman yang diberikan}

Piutang dan pinjaman yang diberikan dimiliki oleh semua perusahaan sampel dalam penelitian ini, yaitu sebanyak 245 perusahaan. Semua perusahaan yang mempunyai piutang dan pinjaman yang diberikan menggunakan metode biaya untuk mengukur aset dan keuangan keuangan tersebut. Tidak ada perbedaan kebijakan antara tahun 2009 dan 2010, semua perusahaan masih menggunakan metode yang sama (metode biaya). Sehingga berdasarkan indeks-T didapatkan poin 1.000 untuk tingkat daya banding.

Hasil penelitian ini tidak sejalan dengan penelitian Cairns et al.untuk daya banding aset keuangan, baik UK maupun Australia mengalami penurunan daya banding laporan keuangan setelah menggunakan pengukuran nilai wajar IFRS. Untuk kewajiban keuangan, perusahaan-perusahaan di UK terjadi penurunan daya banding dan untuk Australia sejalan dengan penelitian di Indonesia, yaitu tidak ada perubahan.Perbedaan hasil ini karena sampel yang digunakan oleh Cairns et al. meliputi perusahaan keuangan sedangkan penelitian ini mengeluarkan sektor keuangan.Disamping itu, kemungkinan metode adopsi IFRS dan perbedaan pasar modal antara perusahaan di negara maju dan 
negara berkembang.

\section{SIMPULAN}

Pengukuran nilai wajar-konvergensi IFRS tidak sama perlakuan untuk kebijakan akuntansi, ada yang diwajibkan menggunakan nilai wajar dan ada yang diberikan pilihan metode pengukuran.Ada dua kebijakan akuntansi dalam penelitian ini yaitu instrument diperdagangkan dan tersedia dijual.Hasil penelitian menunjukkan bahwa kedua instrumen tersebut menunjukkan tidak ada peningkatan daya banding.

Tidak adanya peningkatan daya banding karena sebelum implementasi PSAK 55, yaitu pada tahun 2009, perusahaan sudah mengukur kedua instrumen tersebut dengan menggunakna nilai wajar.Hal ini dimungkinkan karena masa disahkan dengan tanggal efektif mengalami jeda yang cukup lama, dari 2006 - 2010. Bahkan PSAK 55 awalnya ditetapkan tanggal efektif pada tahun 2009, namun banyak lembaga keuangan baik bank maupun non bank yang tidak siap, maka mundur menjadi tahun 2010. Hal ini yang mungkin mempengaruhi tidak adanya perubahan daya banding.Meskipun demikian, indeks- $T$ menyajikan hasil tingkat daya banding laporan keuangan yang tinggi, yaitu untuk instrumen diperdagangkan sebesar 1 dan instrumen tersedia dijual sebesar 0.867.

Untuk kebijakan akuntansi yang diperbolehkan memilih pengukuran antara metode biaya dan nilai wajar tidak ada perubahaan daya banding sebelum dan ketika penerapan, kecuali aset tetap.Aset properti investasi, aset takberwujud, instrumen keuangan dimiliki sampai jatuh tempo serta piutang dan pinjaman yang diberikan tidak ada perubahan. Namun demikian, tingkat indeks-T daya banding masih tinggi yaitu sebesar, masing-masing, 0.876 untuk properti investasi; 1 untuk aset takberwujud, instrumen keuangan diperdagangkan, serta piutang dan pinjaman yang diberikan; dan 0.867 untuk instrumen keuangan tersedia dijual. Daya banding untuk aset tetap malah meningkat, hal ini tidak sesuai dengan hipotesis awal.Tingkat daya banding untuk aset tetap sebesar 0.987.
Tidak berpengaruhnya tingkat daya banding laporan keuangan membuat implikasi bahwa PSAK tentang nilai wajar tidak cukup direspon oleh penyedia informasi keuangan, kecuali untuk aset tetap yang mengalami peningkatan.Hal ini karena memang nilai wajar tidak mudah untuk dilakukan karena masalah keandalan. Selain itu, ketika harga di pasar sulit didapat perusahaan akan melakukan appraisal untuk menilai nilai wajar dan ini menimbulkan konstrain berupa penambahan biaya. Padahal manfaat nilai wajar masih kurang dirasakan oleh perusahaan.Bahkan, penelitian terdahulu (Farahmita dan Siregar, 2014) menemukan bahwa ada kecenderungan penghindaran pajak yang menjadikan alasan mengapa perusahaan masih tidak melakukan pengukuran nilai wajar.Jika demikian, maka dewan standar untuk saat ini tidak perlu melakukan evaluasi terhadap pengukuran nilai wajar karena memang masih menunjukkan tingkat daya banding yang tinggi.

Penelitian ini menggunakan indeks Taplin dengan melakukan content analysis untuk menentukan daya banding yang berskala 0 sampai 1. Dalam melakukan content analysis, jika perusahaan melakukan Penelitian selanjutnya dapat melakukan investigasi daya banding dengan menggunakan pendekatan angka akuntansi, karena penelitian ini tidak dapat menangkap daya banding secara angka akuntansi yang disajikan. Disamping itu, perlu dilakukan pengujian relevansi nilai untuk masingmasing PSAK, karena kualitas laporan keuangan disamping harus dapat diperbandingkan juga harus relevan.

\section{DAFTAR PUSTAKA}

Allen, F., \& E. Carletti.(2008). Mark-toMarket Accounting and Liquidity Pricing. Journal of Accounting and Economisc pp. $358-378$

Barth, M.E., Beaver, W.H., Landsman, W.R., (1994).Value-Relevance of Bank's Fair Value Disclosure Under SFAS No. 107. The Accounting Review. Vol. 71, No. 4, October 1996 pp. 513 - 537 
Barth, Mary E, et al. (2012). Are IFRS-Based and US GAAP-Based Accounting Amounts Comparable?Journal of Accounting and Economics. 54. Pg 6893

Bartov, E., Goldberg, S. R., \& Kim, M. (2005).Comparative Value Relevance among German, US and International Accounting Standards: A German Stock Market Perspective. Journal of Accounting Auditing \& Finance, 20(2), 95- 119.

Bratten, B., Causholli M., Khan, U., (2012). Fair Value Acconting and the Predictive Ability of Earning: Evidence from the Banking Industry. Electronic copy available at: http://ssrn.com/abstract=2165996

Cairns, David, et al. (2011). IFRS Fair Value Measurement and Accounting Policy Choice in the United Kingdom and Australia.The British Accounting Review. 43 1-21

Catuogno, Simona \& Alini, Allessandra. 2011. Multiple Evaluation Option \& Comparability: Equity Investment in Italy and Spain. Accounting \& Management System. Vol. 10, No. 2, pp. $249-274$

Cheng, Cheng, Kin Lo, Desmond Tsang, Jing Zhang. (2013). Earnings management, firm location, and financial reporting choice: An analysis of fair value reporting for investment properties in an emerging market. Working Paper.The Canadian Academic Accounting Association Conference

Christensen, Hans B, Nikolaev, Valeri. (2009). Who Uses Fair Value Accounting for Non-Financial Asets after IFRS Adoption?. Working Paper No. 09-12. The University of Chicago Booth School of Business. The Electronic copy available at: http://ssrn.com/abstract=1269515

Cooper, Donald R., \& Schindler, Pamela S. (2011).Business Research Methods.(Eleventh Edition). Mc Graw Hill: USA
Danbolt, J. and Rees, W. (2008).An experiment in fair value accounting: UK investment vehicles. European Accounting Review 17(2):pp. 271-303.

DeFranco, G, Kothari, S., Verdi, R.S., (2011).The Benefits of Financial Statement Comparability. Journal ofAccounting Research, 49: 895-931.

Dietrich, J. Richard, Mary S. Harris, Karl A. Muller. (2001). The reliability of investment properti fair value estimates. Journal of Accounting and Economics 30 (2001) 125\}158

Dixon, Jhon \& Frolova, Yuliya. (2013). Accounting for Good Governance: the Fair Value Challage", CORPORATE GOVERNANCE VOL. 13 NO. 3 2013, pp. 318-331, Emerald Group Publishing Limited, ISSN 1472-0701

Epstein, Barry J., and Jermakowicz, Eva K. (2008). IFRS 2008: Interpretation and Application of International Financial Reporting Standards. Canada, John Wiley \& Sons.

Farahmita, Aria \& Siregar, Sylivia Veronica. 2014. Faktor-Faktor yang Mempengaruhi Kemungkinan Perusahaan Memilih Metode Nilai Wajar untuk Properti Investasi. Dipresentasikan di Simposium Nasional Akuntansi (SNA) 17, Lombok, 24 - 26 September 2014-1012

Field, T., Lys, T., \& Vincent, L. (2001).Empirical Research on Accounting Choice.Journal of Accounting and Economics. 31. 255 307

Gladney, John. (2011). An Analysis of Fair Value Accounting in the Banking Industry. (Dec, 2011). http://ssrn.com/abstract:2181153, diakses pada 3/6/2014

Herrmann, D., Saudagaran, S.M., \& Thomas, W.B. (2006).The Quality of Fair Value Measure for Property, Plant, and Equipment. Accounting Forum 30 (2006) 43-59 
Ikatan Akuntan Indonesia. (2007). Standar Akuntansi Keuangan Per 1 September 2007. Salemba Empat

Ikatan Akuntan Indonesia. (2012). Standar Akuntansi Keuangan Per 1 Juni 2012. IAI

Ikatan Akuntan Indonesia. (2013). PSAK 68: Pengukuran Nilai Wajar. IAI

Ishak, Hani Soraya; Tahir,Henny Hazliza Mohd; Ibrahim,Muhd Kamil; El Wahab, Wael Adb. (2012). Determinants of Accounting for Investment Properti (Frs140) In Properti Sector: Evidence From Malaysia. $3^{\text {rd }}$ International Conference on Business and Economic Research (3rd Icber 2012) Proceeding. - 13 march 2012. Golden Flower Hotel, Bandung, Indonesia

Kang Cheng. (2007). "Fair Value Option for Financial Aset: an Opportunity for Earning Management". Working Paper.Commercial Lending Review. January - February 2007

Kieso, Donald E., Jerry J. Weygandt, and Terry D. Warfield. 2011. Intermediate Accounting. Volume 1, IFRS Edition. Wiley and Sons: USA

Lauz, C \& Leuz, C. (2010).Did Fair-Value Accounting Contribute to the Financial Crisis?.Journal of Economic Perspectives.Volume 24, Number 1 Winter. Pages 93-118

Maruli, S. \& Farahmita, A. (2010).Analisis Pendekatan Nilai Wajar dan Nilai Historis dalam Penilaian Aset Biologis pada Perusahaan Aglikultur: Tinjuan Kritis Rencana Adopsi IAS 41. Simposium Nasional Akuntansi (SNA) XIII, Purwokerto

Muller. K.A., Riedl. Edward J.,\& Sellhorn. T. (2008).Causes and Consequences of Choosing Historical Cost versus Fair Value.Working Paper.Harvard Business School.

Nurasiah \& Nuryani, N. (2014). Relevansi Nilai serta Implikasi Risiko atas Keuntungan dan Kerugian Perubahan Nilai Wajar Kewajiban Perbankan
Indonesia. Simposium Nasional Akuntansi (SNA) XVII, Lombok, NTB

Parker, R., \& Morris, R. (2001).The Influence of US GAAP on the Harmony of Accounting Measurement Policies of Large Companies in the UK and Australia.Abacus. 37 (3), 297 - 328

Peng, Songlan \& Kathryn Bewley. (2010). Adaptability Fair Value Accounting in an Emerging Economy: A Case Study of China's IFRS Convergence. Accounting, Auditing, and Accountability Journal Vol 23 No. 8 2010, Emerald Group Publishing Limited

Quagli.A.,\& Avallone. F. (2010).Fair Value or Cost Model?Drivers of Choice for IAS 40 in the Real Estate Industri.European Accounting Review.Vol 19.No. 3. 461 - 493.

Scoot, W.R. (2012). Financial Accounting Theoty (sixth Edition). Pearson: USA

Sugiyono.(2011). Metode Penelitian Kombinasi (Mixed Methods). Alfabeta: Yogjakarta

Taplin, R. (2004). A Unified Approach to the Measurement of International Accounting Harmony. Accounting and Business Researh, 34 (1), 57 - 73

Taplin, R. (2010). Statistical Inference Using the $T$ Index to Quantify the Level of Comparability between Accounts. Accounting and Business Research, 40 (1), 75-104

Taplin, R. (2011). The Measurement of Comparability in Accounting Research.ABACUS. A Journal of Accounting, Finance, and Business Studies, Vol 47, No. 3, 2011

Taplin, Ross; Yuan, Wei; and Brown, Alistair.(2014).The Use of Fair Value and Historical Cost Accounting for Investment Properties in China. Australasian Accounting, Business and Finance Journal, 8(1), 2014, 101-113. Available at:http://ro.uow.edu.au/aabfj/vol8/iss 1/6 Taylor, Dennis W. (2009). Cost-Benefit of Adoption of IFRS in Countries with different harmonization 
SITI KHOMSATUN / Penerapan Pengukuran Nilai Wajar PSAK-Konvergensi IFRS dan Dampaknya Pada Pilihan Kebijakan Akuntansi di Indonesia

histories.Emerald Group Publishing Limited. Asian Review of Accounting Vol. 17 No. 1, 2009 pp. 40-58

Watts, Ross, Zimmerman, Jerold, L. (1986). Positive Accounting Theory. Prentice Hall, New Jersey. United States of America, 1986.

Wiyono, G.W., 2011. Merancang Penelitian Bisnis dengan Alat Analisis SPSS dan SmartPLS. UPP STIM YKPN: Yogjakarta

Yi-Ping Liao. (2013). The Impact of FairValue-Accounting on the Relevance of Capital Adequacy Ratio: Evidence from Taiwan. Managerial Finance Vol. 39, No. 2, 2013, pp 133 - 154, Emerald Group Publising Limited 